\title{
Summary Report An Exploratory Study of Cost Targets for Solar Electric Power Plants
}

T. D. Anderson

H. I. Bowers

J. G. Delene

L. C. Fuller

S. I. Kaplan

J. V. Wilson

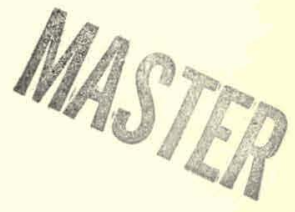

\section{OAK RIDGE NATIONAL LABORATORY}

OPERATED BY UNION CARBIDE CORPORATION FOR THE ENERGY RESFARCH AND DLVELUPMENT ADMINISTRATION 


\section{DISCLAIMER}

This report was prepared as an account of work sponsored by an agency of the United States Government. Neither the United States Government nor any agency Thereof, nor any of their employees, makes any warranty, express or implied, or assumes any legal liability or responsibility for the accuracy, completeness, or usefulness of any information, apparatus, product, or process disclosed, or represents that its use would not infringe privately owned rights. Reference herein to any specific commercial product, process, or service by trade name, trademark, manufacturer, or otherwise does not necessarily constitute or imply its endorsement, recommendation, or favoring by the United States Government or any agency thereof. The views and opinions of authors expressed herein do not necessarily state or reflect those of the United States Government or any agency thereof. 


\section{DISCLAIMER}

Portions of this document may be illegible in electronic image products. Images are produced from the best available original document. 


\section{Printed in the United States of America. Available from National Technical Information Service}

U.S. Department of Commerce

5285 Port Royal Road, Springfield, Virginia 22161

Price: Printerd Conpy $\$ 4 \mathrm{nn}$; Microfiche $\$ 3.00$

This report was prepared as an account of work sponsored by the United States Government. Neither the United States nor the Energy Research and Development Administration/United States Nuclear Regulatory Commission, nor any of their employees, nor any of their contractors, subcontractors, or their employees, makes any warranty, express or implied, or assumes any legal liability or responsibility for the accuracy, completeness or usefulness of any information, apparatus, product or process disclosed, or represents that its use would not infringe privately owned rights. 
Contract No. W-7405-eng-26

Engineering Technology Division

SUMMARY REPORT

AN EXPLORATORY STUDY OF COST TARGETS

FOR SOLAR ELECTRIC POWER PLANTS

T. D. Anderson

H. I. Bowers

J. G. Delene

L. C. Fuller

S. I. Kaplan

J. V. Wilson

This report was prepared as an account of work sponsored by the United States Government. Neither the United States not the United States Energy their emplovelopment Administration, not any of subcontractors, or their of heit contractors, warranty, express or implied, or assumes any any lability of responsibility for the accuracy, comple legal or usefulness of any information, apparatus, ppoduct or prosess disclosed. it represents that its use would not infringe privately owned rights.

Date Published - March 1977

Prepared for the

Division of Solar Energy

OAK RIDGE NATIONAL LABORATORY

Oak Ridge, Tennessee 37830

operated by

UNION CARBIDE CORPORATION

for the

ENERGY RESEARCH AND DEVELOPMENT ADMINISTRATION 


\section{THIS PAGE}

\section{WAS INTENTIONALLY \\ LEFT BLANK}


CONTENTS

$\underline{\text { Page }}$

ACKNOWLEDGMENTS . . . . . . . . . . . . . . . . . . . V V

ABSTRACT . . . . . . . . . . . . . . . . . . . . . . I I

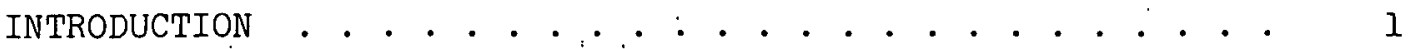

APPROACH AND SCOPE . . . . . . . . . . . . . . . . 2

SUMMARY OF RESULTS . . . . . . . . . . . . . . . . . . 3

The Future Conventional Energy Mix . . . . . . . . . 3

Conventional Power Plant Economics . . . . . . . . . 4

Cost Targets for Solar and Wind Power Plants . . . . . . 9

Cost Targets for OTEC Power Plants . . . . . . . . . 22

CONCLUSIONS AND RECOMMENDATIONS • . . . . . . . . . . . 29

REFERENCES . . . . . . . . . . . . . . . . . . . . . 31 
THIS PAGE

WAS INTENTIONALLY

LEFT BLANK 


\section{ACKNOWLEDGMENTS}

The authors gratefully acknowledge the contributions of staff members of the ERDA Division of Solar Energy and especially those of James Rannels, who provided guidance throughout the course of the work, and Paul Maycock who made a number of helpful suggestions. Special thanks are in order to Georgia C. Bower for preparing the manuscript and to Jane C. Parrott for preparing the illustrations. 
SUMMARY REPORT

AN EXPLORATORY STUDY OF: COST TARGETS

FOR SOLAR ELECTRIC" POWER PLANTS

$\begin{array}{ll}\text { T. D. Anderson } & \text { L. C. Fuller } \\ \text { H. I. Bowers } & \text { S. I. Kaplan } \\ \text { J. G. Delene } & \text { J. V. Wilson }\end{array}$

ABSTRACT

A preliminary evaluation was made of the economic goals that need to be achieved in the solar-electric R\&D and demonstration programs so that solar can become a viable component of our riational electric energy production system. Solar electric technologies considered are: solar thermal conversion, solar photovoltaic, wind energy conversiọn, and ocean thermal. Target costs. were developed for selected applications of solar by comparison with known means of accomplishing the same end results. The known technologies were assumed to be fossil and nuclear energy sources.

\section{INTRODUCTION}

Solar energy has been proposed as a solution to a wide variety of our energy problems as shown in Table 1. The major programs supported by the ERDA Division of Solar Energy are on electricity production and heating/ cooling of buildings. As indicated in Table 2, ERDA has assigned the highest priority to solar-electricity production. I Four solar technologies are under development for producing electricity; these are

1. Ocean Thermal Energy Conversion,

2. Solar Thermal Energy Conversion,

3. Solar Photovoltaic Energy Conversion, and

4. Wind Energy Conversion.

The purpose of the present study was to conduct a preliminary evaluation of the economic goals that need to be achieved in the solar-electric R\&D and demonstration programs so that solar can become a viable component of our national electric-energy production system. This Summary Report presents the major findings of the investigation. Details of the work are given in the main report. 2 
Table 1. Solar has been proposed as a solution to a variety of energy problems

1. Electricity production

2. Thermal energy for agriculture and industry

3. Heating and cooling of buildings

4. Fuel production

5. Pumping

Table 2. ERDA's major solar programs are on electricity production and heating-cooling of buildings

Highest priority - Electricity production

Moderate priority - Heating and cooling

APPROACH AND SCOPE

There are two questions that need to be answered to determine the economic feasibility of solar or any new energy technology. First, what. does it cost and, second, what is it worth? If the worth is equal to or greater than the cost, then one can say that economic feasibility has been demonstrated. ERDA has a number of design and cost studies underway to estimate the expected cost range for each of the four solar-electric technologies: Thus, the present study did not address cost but dealt, instead, with the question of worth or value. The values of solar technologies were determined by comparison with known means of accomplishing the same end results. In this study the known technologies are fossil and nuclear energy sources; no significant advancements beyond present technology for these energy sources were assumed. 
The study consisted of the following elements:

1. Cursory review of previous solar-electric studies and evaluations.

2. Selection of a future national mix of conventional energy generation systems and development of representative capital investments, O\&M costs, and fuel prices for the conventional systems.

3. Analysis of selected potential roles for solar electric technologies and development of cost targets for each potential role.

It should be emphasized that the scope of the present study did not include evaluations of either the cost or technical feasibility of proposed solar-electric technologies. Neither did the study consider the intangible benefits that might accrue from the substitution of solar for other energy sources. The results are limited to economic goals and no attempt was made to determine whether the goals can be met. This is, of course, a key question but it is being addressed in other ERDA-SOLAR programs.

\section{SUMMARY OF RESULTS}

\section{The Future Conventional Energy Mix}

Since most solar energy projections.indicate that major market penetrations will occur after the turn of the century, the year 2000 was chosen as the reference period for purposes of the present study. A.number of forecasts have been made by both government and private groups concerning the future makeup of the electric energy supply system. Groups that have made projections include ERDA, ${ }^{3}$ the Federal Energy Administration, ${ }^{4}$ the Department of Interior, ${ }^{5,6}$ and the Electric Power Research Institute. 7 Although there is not complete agreement among the various forecasts, they all indicate that coal and nuclear will provide the major share of electricity generation by the turn of the century. For the present study, the national energy-system mix embodied in the ERDA Planning and Analysis projections (moderate low case) of 1975 (Ref. 3) was adopted. Any of the 
other projections mentioned above could have been used, however, with little effect on the study results. The assumed distribution of conventional capacity and generation is shown in Table 3.

\section{Conventional Power Plant Economics}

Capital investments, 0\&M costs, and fuel prices were developed on a consistent basis for conventional power plants including:

1. Light water reactors, wet cooling tower, 2-unit station with total capacity of 2400 MWe.

2. Coal-fired steam plant burning high-sulfur coal, wet cooling tower, stack-gas scrubbers, 3-unit station with total capacity of 2400 MWe.

3. O1l-fired steam plant burning low-sulfur residual oil, 3-unit station with total capacity of 2400 MWe.

4. Simple-cycle gas turbine burning, distillate oil, 100 MWe units.

Capital and nonfuel O\&M

Estimated capital investments for conventional power plants are shown in Table 4. The costs, which are expressed in mid-1976 dollars, range from $\$ 125 / \mathrm{kW}$ for simple-cycle gas turbines to $\$ 731 / \mathrm{kW}$ for light-water nuclear power plants.

Operation and maintenance costs are given in Table 5. The O\&M costs are separated into fixed and variable components. Fixed costs are those independent of energy generated on an annual basis. Variable costs are directly proportional, on an annual basis, to the energy generated.

\section{Fuel prices}

The future price level of conventional fuels is the single most important element in determining the competitive position of solar energy. In this study, consistent sets of fuel prices were derived based on the assumption that, in the long run, the prices of all utility fuels will bear a competitive* relationship to each other. There is ample evidence that

*"Competitive" does not necessarily mean that prices will fall to that of the lowest cost fuel. More likely, prices will rise to the cost of the major fuel. 
Table 3. Year 2000 national electric energy system mix

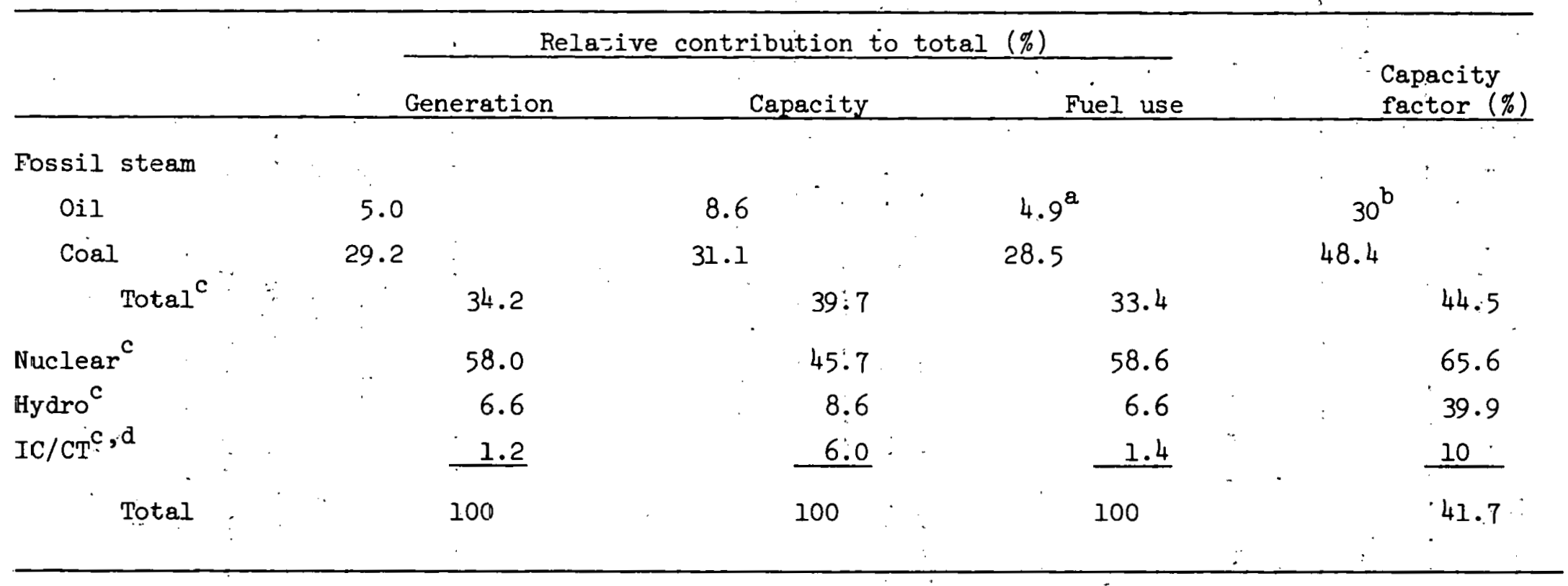

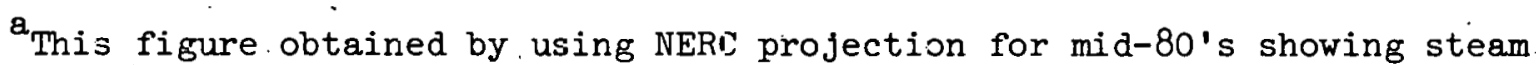
generation from oil uses 23.5 times fuel that IC/CT use.'

$\mathrm{b}_{30 \%}$ plant factor assumed for oil.

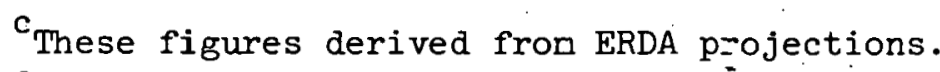

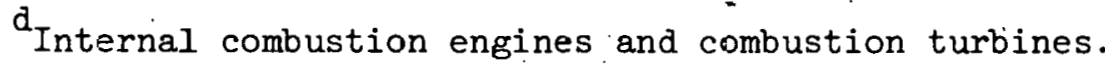


Table 4. Summary of conventional power plant capital cost estimates (mid-1976 dollars)

\begin{tabular}{lc}
\hline Power plant & $\begin{array}{c}\text { Unit capital } \\
\text { investment } \\
(\$ / \mathrm{kW})\end{array}$ \\
\hline Light water reactor & 731 \\
Coal steam, with scrubbers & 612 \\
Oil steam & 417 \\
Gas turbine & 125 \\
Hydroelectric & 525 \\
\hline
\end{tabular}

Table 5. Nonfuel operation and maintenance costs for conventional power plants (mid-1976 dollars)

\begin{tabular}{lcc}
\hline \multirow{2}{*}{ Power plant } & \multicolumn{2}{c}{ O\&M costs } \\
\cline { 2 - 3 } & $\begin{array}{c}\text { Fixed } \\
(\$ / \mathrm{kW} . \mathrm{yr})\end{array}$ & $\begin{array}{c}\text { Variable } \\
(\mathrm{mills} / \mathrm{kW} . \mathrm{hr})\end{array}$ \\
\hline Light water reactor & 4.74 & 0.04 \\
Coal steam, with scrubbers & 8.12 & 1.34 \\
Oil Steam & 4.81 & 0.01 \\
Gas turbine & 0.70 & 3.60 \\
Hydroelectric & 4.00 & 0.01 \\
\hline
\end{tabular}

this is a valid assumption; the most recent is the upward movement of the prices of coal and uranium in response to the rising price of oil, the world's dominant energy source. In the assumed year-2000 energy mix, uranium is the dominant electricity-producing fuel. It seems reasonable, therefore, that other fuels used in electricity production will be keyed to the price of nuclear energy.

The procedure used to develop consistent sets of utility fuel prices is as follows: 
1. Assume price of nuclear fuel.

2. Determine competitive prices of fossil fuels so that each power plant would be an economic choice in the range of capacity factors for which it is most commonly operated.

In establishing nuclear fuel prices, it was assumed that light water reactors (LWRs) constitute the only nuclear choice (i.e., no breeder reactors). Key components in the LWR fuel cycle are uranium ore $\left(\mathrm{U}_{3} \mathrm{O}_{8}\right)$ and separative work with ore being the more important. The range of ore prices assumed for the year 2000 was $\$ 150$ to $\$ 440 / \mathrm{kg} \mathrm{U}_{3} \mathrm{O}_{8}\left(\$ 68\right.$ to $\$ 200 / 1 \mathrm{~b} \mathrm{U} \mathrm{U}_{3} \mathrm{O}_{8}$ ). Since the price of ore varies with time, the stated figures are levelized values for a nuclear plant starting up in 2000 . The $\$ 150 / \mathrm{kg}$ figure is based on the assumption that both uranium demand and uranium resources will be within present predictions. If so, the $\$ 440 / \mathrm{kg} \mathrm{level,} \mathrm{which}$ represents the expected price if uranium must be extracted from low-grade deposits such as Chattanooga shale, would not be reached until well after the year 2000. Nevertheless, if the demand for uranium is appreciably higher than expected or if the resources are less than estimated, it is conceivable that the price could reach $\$ 440 / \mathrm{kg} \mathrm{U}_{3} \mathrm{O}_{8}$ by the turn of the century. Thus the $\$ 440 / \mathrm{kg}$ price was adopted as the "high" level for the year 2000 .

The derived competitive sets of fuel-prices are shown in Table 6 . These year-2000 prices (expressed in mid-1976 dollars) are higher than present-day (mid-197.6) prices by approximately the following amounts: 175 to $700 \%$ for uranium; 20 to $165 \%$ for eastern delivery of coal; and 0 to $100 \%$ for oil. It should be noted that the fuel prices are intended to be representative on a national:basis. Regional variations were not considered even though these could be very important, especially for coal.

The fuel portion of electricity production costs, based on the above fuel prices, is shown in Table 7.. Fuel unit costs range from 7.4 mills/ $\mathrm{kW} . \mathrm{hr}$ for nuclear at the nominal fuel-price level to $50.7 \mathrm{mills} / \mathrm{kW} . \mathrm{hr}$ for gas turbines at the high fuel-price level. 
Table 6. Consistent sets of competitive fuel prices, year. 2000 (mid-1976 dollars)

\begin{tabular}{|c|c|c|}
\hline & \multicolumn{2}{|c|}{ Price } \\
\hline & Nominal & High \\
\hline \multicolumn{3}{|l|}{ Uranium ore, } \\
\hline$\$ / 1 b \quad U_{3} \mathrm{O}_{8}$ & 68 & 200 \\
\hline$\$ / \mathrm{kg}_{3} \mathrm{U}_{3} \mathrm{O}_{8}$ & 150 & 440 \\
\hline \multicolumn{3}{|c|}{ High sulfur coal, } \\
\hline$\$ /$ ton & 24 & 53 \\
\hline$\$ / 1000 \mathrm{~kg}$ & 26 & 58 \\
\hline \multicolumn{3}{|c|}{ Low sulfur coal, } \\
\hline$\$ /$ ton & $: 28$ & 49 \\
\hline$\$ / 1000 \mathrm{~kg}$ & 31 & 54 \\
\hline \multicolumn{3}{|l|}{ Residual oil, } \\
\hline$\$ / \mathrm{bbl}$ & 14 & 21 \\
\hline$\$ / m^{3}$ & 88 & 132 \\
\hline \multicolumn{3}{|c|}{ Distillate oil, } \\
\hline$\$ / \mathrm{hhl}$ & 19 & 24 \\
\hline $4 / u^{3}$ & 120 & 1.51 \\
\hline
\end{tabular}

Table 7. Fuel contribution to energy generation costs for year 2000 (mid-1976 dollars)

\begin{tabular}{|c|c|c|}
\hline \multirow{2}{*}{. } & \multicolumn{2}{|c|}{ Fuel cost (millc $/ \mathrm{kW}, \mathrm{hr}$ ) } \\
\hline & Nominal & High \\
\hline Nuclear, * LWR & 7.4 & 16.8 \\
\hline Coal-fired steam plant & 9.5 & 20.9 \\
\hline Oil-fired steam plant & 21.3 & 32.8 \\
\hline Gas turbine & 39.3 & 50.7 \\
\hline
\end{tabular}

*70\% capacity factor. 
Energy production costs

The estimates of costs for capital, operation and maintenance, and fuel were combined to obtain total generation cost for each of the conventional power plants; the results are shown in Fig. 1.

\section{Cost Targets for Solar and Wind Power Plants}

Supplemental power

Because the wind and sun are variable, and to some extent unpredictable, the direct substitution of solar and wind power plants for conventional power plants gives rise to complex questions concerning system reliability; the subject of direct substitution of solar for conventional power plants will be discussed later.

One clear-cut and potentially useful application of solar and wind power plants is as supplemental power (energy-displacement) in a system consisting of conventional power plants. The supplemental power application does not require energy storage.* In addition to fuel savings, supplemental power plants would reduce the variable portion of nonfuel O\&M costs associated with conventional power plants. Figure 2 shows the general relationship between conventional fuel prices and the value of supplemental power plants. These data were developed by equating the annual savings in conventional plant variable costs to the annual charges for supplemental power plants. Use of the figure requires the following definition for rating a supplemental power plant:

$$
\text { Effective rating }(\mathrm{kW})=\frac{\text { theoretical annual energy production (kW.hr) }}{\text { hours in a year }} \text {. }
$$

The theoretical annual energy production is defined to be the amount of energy ( $\mathrm{kW} . \mathrm{hr}$ ) that could be generated in a year if there were no mechanical outages, i.e., no forced or scheduled shutdowns for repair or maintenance. The relationship between effective rating and peak or nameplate rating is

* In practice, short-term energy storage could be required to temper transients caused by starting and stopping of units in response to local weather changes. 


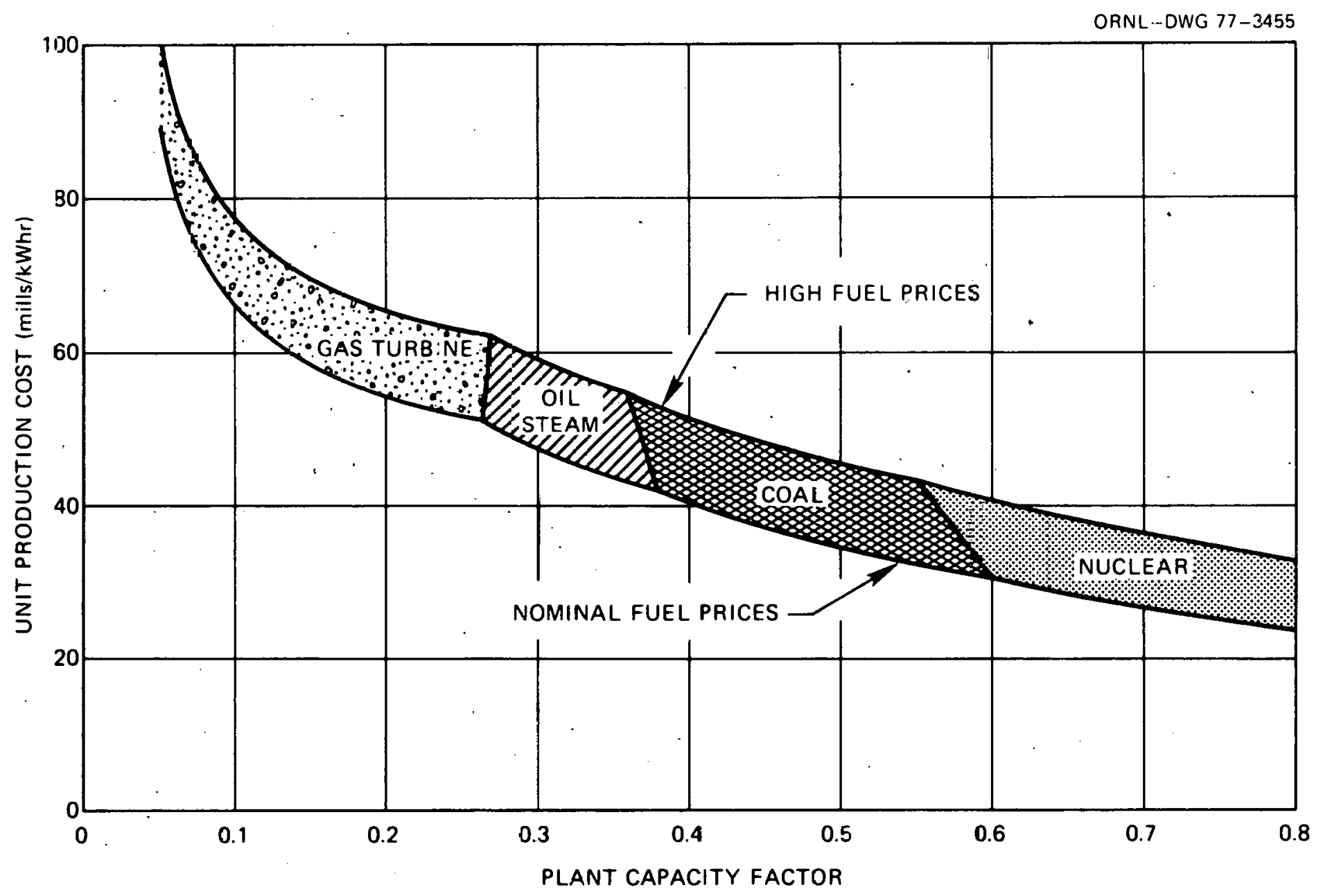

Fig. 1. Energy production costs for conventional power plants, year 20C0, costs in rid-1976 dollars. 


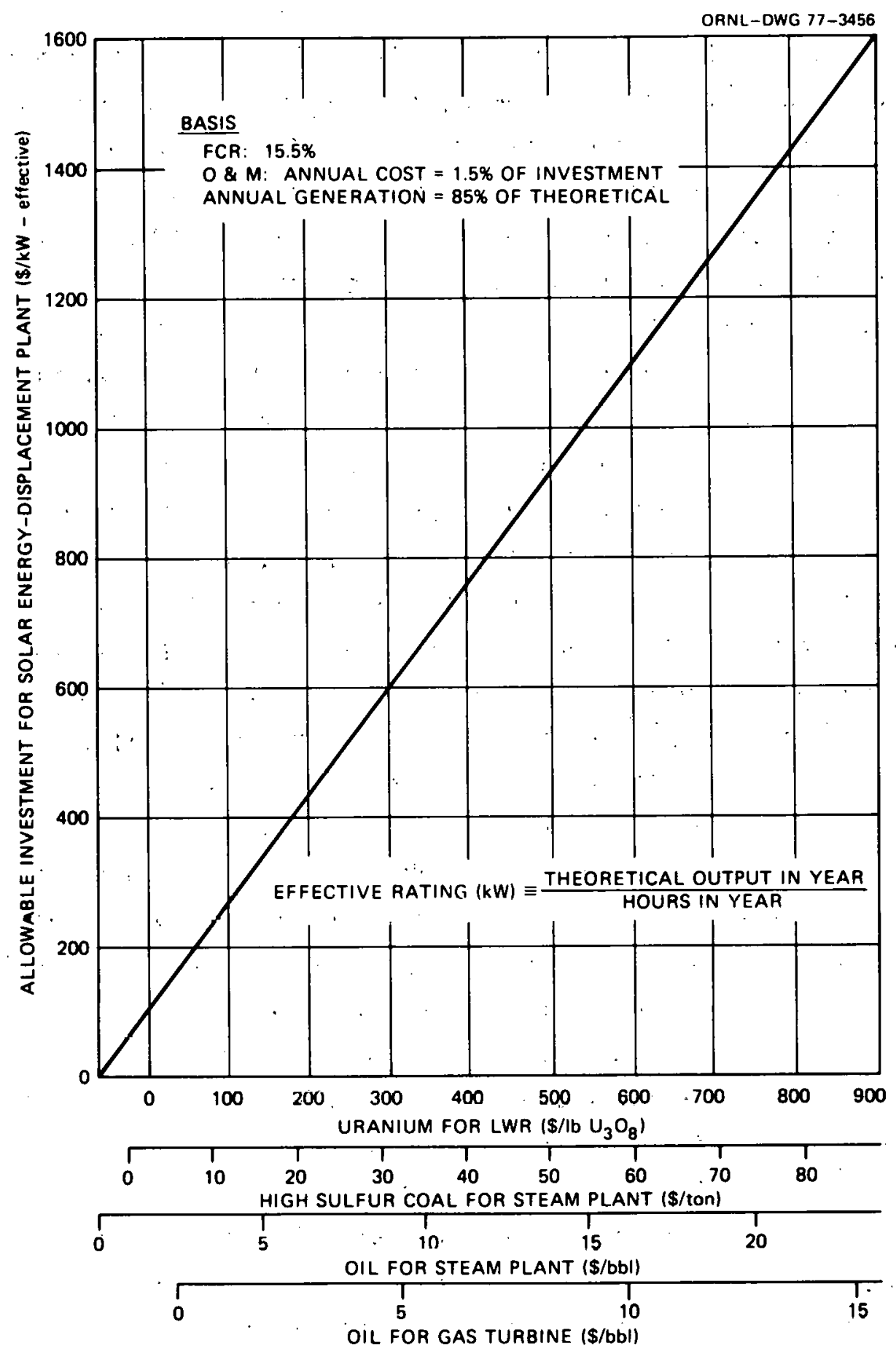

Fig. 2. Cost targets for solar supplemental power plants displacing energy from fossil and nuclear power plants. 
Effective rating $=$ (peak rating) $\mathrm{x}$ (resource availability factor).

The resource availability factor is the theoretical annual energy production expressed as a fraction of the energy that could be generated annually if the machine were to operate at its peak rating all of the time.

To illustrate the application of Fig. 2, suppose the price of residual oil for a steam plant is $\$ 15 / \mathrm{bbl}$. What could one afford to pay for a supplemental power plant to displace energy production from an oil-fired steam plant? From Fig. 2, it is found that the allowable investment is $\$ 1000$ per effective kilowatt. It should he nnted that this result is independent of the location or design of the supplemental power plant. The allowable investment per peak kilowatt is, however, dependent on the site and design of the supplemental power plant. If the resource availability factor for a supplemental power plant of a particular design and at a specific location were $50 \%$, then the allowable investment per peak kilowatt would be $\$ 500$ for the example given above. Thus, the allowable investment per peak kilowatt can be determined by multiplying the allowable investment per effective kilowatt by the resource availability factor.

It is evident that the actual value of a supplemental power plant in a power system will depend strongly on the makeup of the conventional power system and the prices of fuels. Table 8 shows the value of supple= mental power plants when displacing energy from conventional power plants for the range of year-2000 fuel prices described earlier. As would be expected, energy displacement from oil-burning plants is the best application. Energy displacement from nuclear plants is especialjy unpromising. The reason is that a good portion of the nuclear fuel-cycle cost is fixed (investment in core fissile inventory) on an annual basis.

When adding supplemental power plants to a power system, it would be desirable for each added unit to displace the highest-value fuel available to be displaced. Figure 3 shows the value of supplemental power plants as a function of market penetration based on the national mix of energygeneration described earlier and assuming that the highest priced fuels are displaced first. The results show that the value of supplemental power plants declines as market penetration increases. 
Table 8. Incremental cost of power production and worth of solar supplemental power plamts.witr. year-2000 fuel prices (mid-1976 dollars)

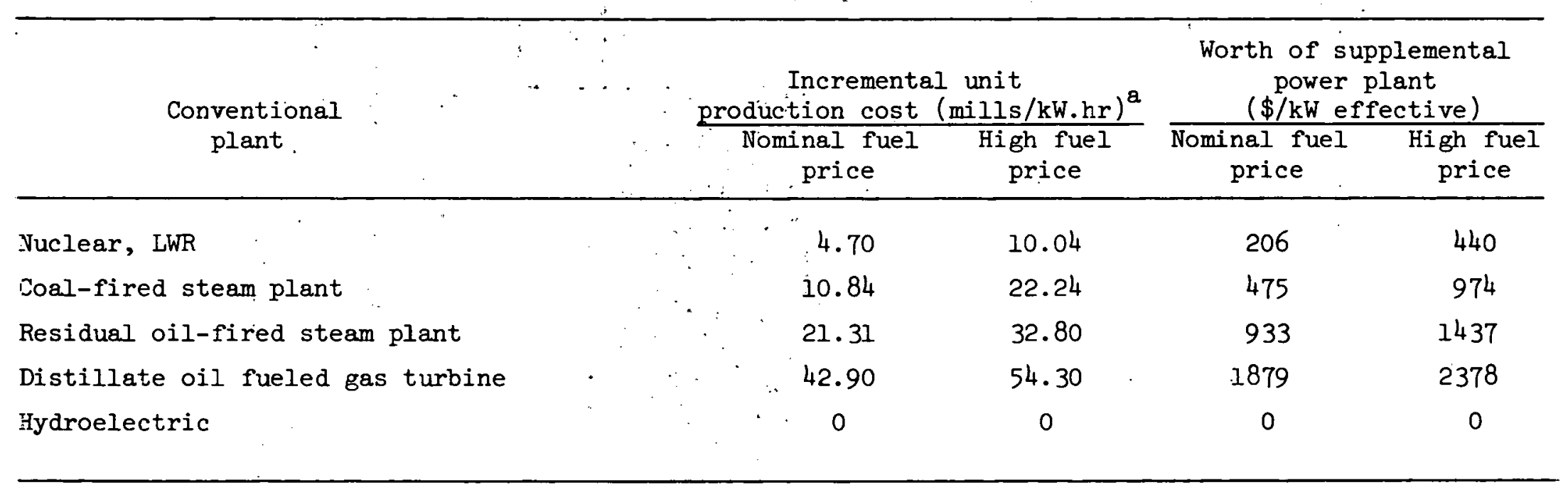

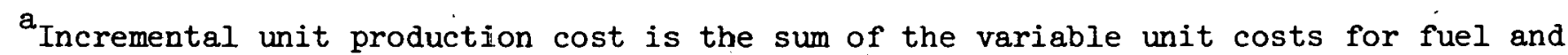
38:M. The variable unit costs for fuel are the total fuel costs for fossil plants but are only a portion of the fuel costs for nuclear plants. 


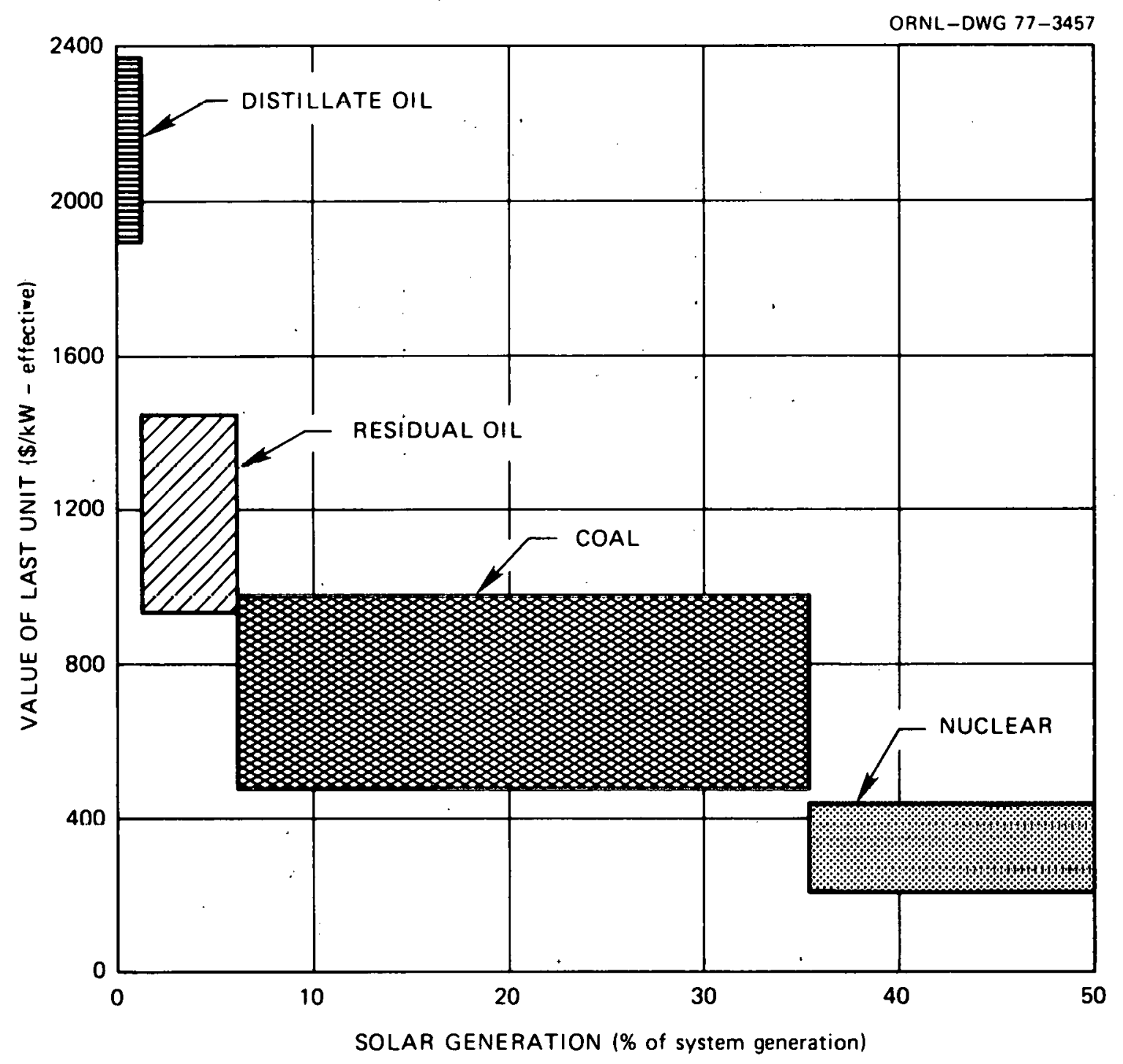

Fig. 3. Cost targets for solar supplemental power plants as function of market penetration in ycar 2000 national energy mix with optimum displacement of conventional fuels. 
In contrast to the ideal energy-displacement assumed above, it will not be possible to pick and choose which fuel is to be displaced.* In reality a mixture of fuels will be displaced, and the value of supplemental power plants will be somewhat less than ideal. To get some indication of this effect, exploratory calculations were made for wind and solar power plants introduced to the Commonwealth Edison system (system composition, load, and weather data for 1973). The results based on the high year-2000 fuel prices are shown in Fig. 4. Indications are that the value of supplemental power plants for small market penetrations may be considerably less than would be expected from the idealized estimate.

The calculation of the values of wind and solar supplemental power plants in the Commonwealth Edison system was made with a load dispatching code (ORSIM) developed at ORNL for a system of conventional power plants. Although it is believed that the results are reasonable, a dispatching code that treats solar and wind power plants in an explicit manner would be desirable and should be developed.

\section{The thermal conversion hybrid}

The hybrid thermal conversion-fossil power plant is a special case of energy-displacement. One example of this concept is shown in Fig. 5. In this arrangement, there is no question about the plant's ability to provide firm power. When solar energy is not available, the fossil boiler picks up the load. The allowable investment for the solar portion of the plant is approximately the same as developed previously for supplemental power plants, but there is a difference. The entire budget can be applied to the solar steam supply system since a separate power conversion system is not required. The advantage is substantial. For example, the power conversion system for a fossil power plant costs approximately $\$ 250 / \mathrm{kW}$ (nameplate rating). The power conversion system for a solar thermal conversion plant would be at least as expensive, and the utilization factor with no energy storage might be $225 \%$. Thus the cost of the power conversion system expressed in dollars per effective kilowatt would be $\$ 1000$.

\footnotetext{
*Note that once a solar or wind supplemental power plant is installed it would be operated in preference to all fuel-burning plants because it would have the lowest incremental operating cost of any plant in the system.
} 


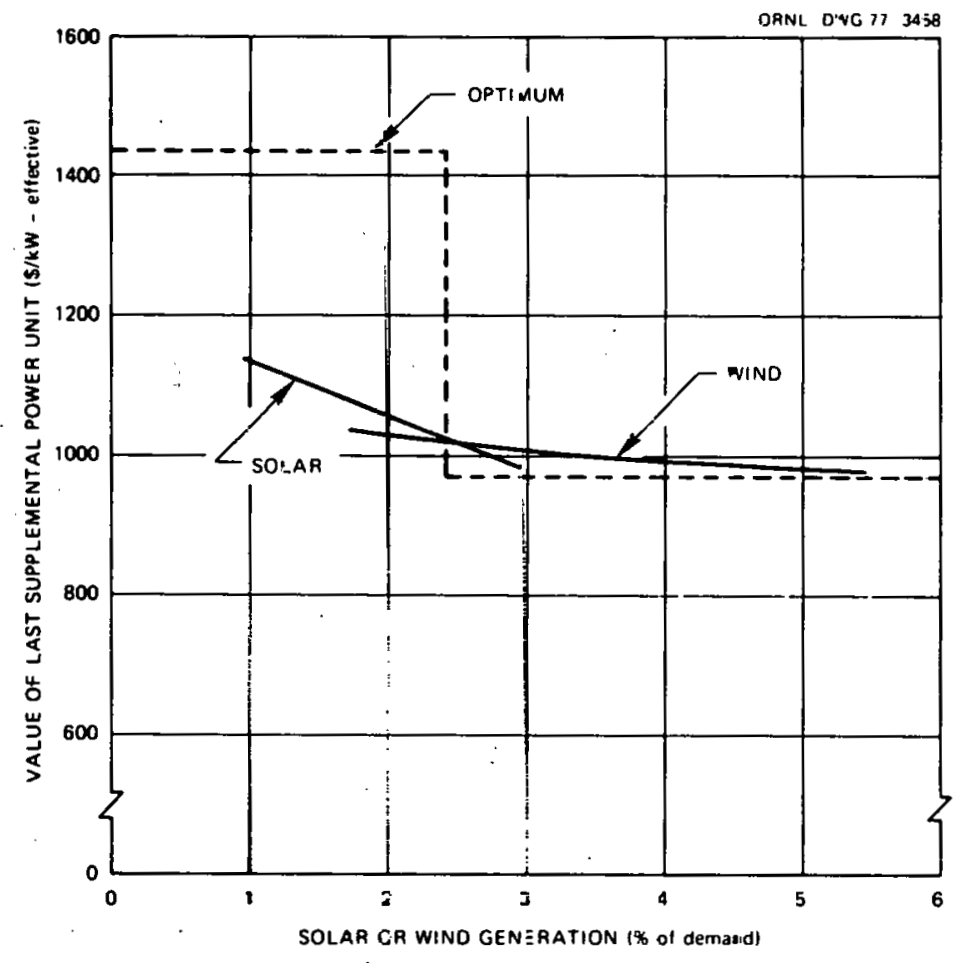

Fig. 4. Value of supplemental power plants, Commonwealth Edison 1973 system, based on high fuel prices for year 2000 .

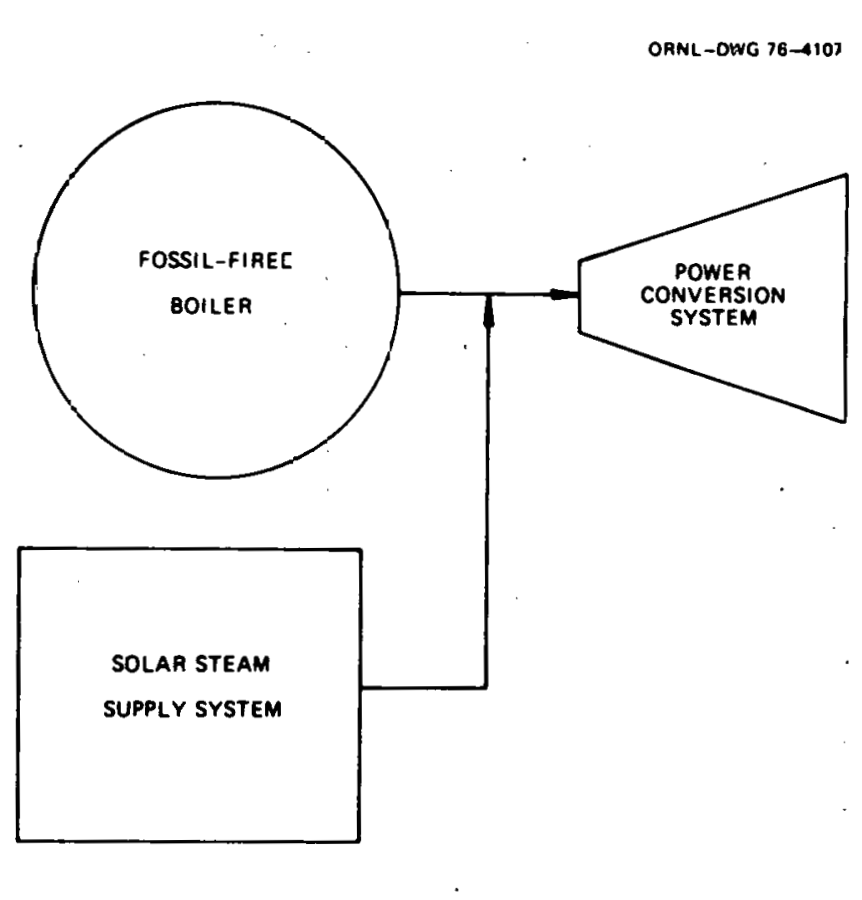

느 
Previously, it was determined that, for the year-2000 nominal fuel prices, the allowable cost of a supplemental power plant displacing residual oil from a steam plant would be $\$ 933$ per effective kilowatt. Since the power conversion system costs $\$ 1000 / \mathrm{kW}$, there would be nothing left to apply to the solar steam supply. For the hybrid power plant, however, the power conversion system is a part of the fossil-fired steam plant, and the entire $\$ 933$ budget could be applied to the solar steam system. It is concluded that the value of a solar steam supply system in a hybrid plant is substantially greater than its value in an isolated solar thermal conversion power plant.

The above suggests an opportunity for early demonstration of solar thermal conversion in a favorable economic envịronment. Some utilities in the Southwest have, substantial capacity in natural-gas fired steam plants. Eventually, regulatory pressure or, perhaps, economics will cause conversion of some plants to oil. By retrofitting existing plants with a supplemental solar steam generator, a savings in high cost fuels could be achieved.

Although the above application would seem to be one of the more promising for solar thermal conversion, it should be kept in mind that retrofitting gas- and oil-fired steam plants has a declining market potential. Presumably few, if any, new oil- or gas-fired steam plants will be built in the future. The best long-term application of the hybrid concept would be in new coal-fired power plants.

The above discussion glosses over some potential technical difficulties in the hybrid concept. Turndown limitations on fossil boilers will probably restrict the solar steam supply capacity to some fraction of the power-plant capacity. Boiler efficiency may decrease at off-design conditions so that the value of the supplemental steam supply would be less than calculated. Transients caused by sudden cloud cover could be troublesome, and there could be other technical problems. Nevertheless, the concept warrants detailed design studies by ERDA.

\section{Direct-replacement power plants}

Another potential application of solar or wind power plants is as direct replacements for conventional power plants. The allowable investments 
for nonfuel power plants competing with conventional power plants are shown in Fig. 6 for the range of year-2000 fuel prices discussed earlier. As can be seen the allowable investment is lowest for peaking plants and highest for base-load plants. Table 9 gives the allowable investment for replacing conventional plants at typical capacity factors. It should be emphasized that the indicated allowable budget for a nonfuel plant must cover all elements required to make the power plant perform precisely as does the conventional power plant it replaces. For a solar or wind power plant, these elements may include (1) energy storage capacity, (2) gasturbine or other backup capacity required to maintain system reliability, and (3) the capitalized value of any fuel burned in the backup plants if energy storage capacity is not sufficient to bring the capacity factor up to that of the conventional power plant. Thus, determining the amount that can be afforded for direct-replacement solar or wind power plants is straightforward, but determining the elements required to allow solar or wind power plants to act as direct replacements is much more difficult. Some preliminary studies were made of solar thermal conversion and photovoltaic baṣe-load power plants to get a better understanding of the requirements for direct-replacement solar power plants.

As implied earlier, a solar power plant with little or no energy storage cannot be counted as firm capacity. From a mechanistic viewpoint, even a significant amount of storage would not displace capacity. For example, suppose a base-load solar power plant is constructed with 24 hours of energy storage capacity (energy capacity equal to the full plant output for 24 hours). On the second day of a series of cloudy days, no power would be available from the solar power plant. If the power system consisted of a number of solar plants located in the same climatic region, the entire power system would become innperative under the conditions postulated. This purely mechanistic view of solar capacity displacement is, however, an oversimplification. Any power plant, no matter how unreliable, added to a power system will statistically add some capacity to the system. As the amount of energy storage is increased, a solar or wind power plant will become more reliable and its capacity displacement will increase. 


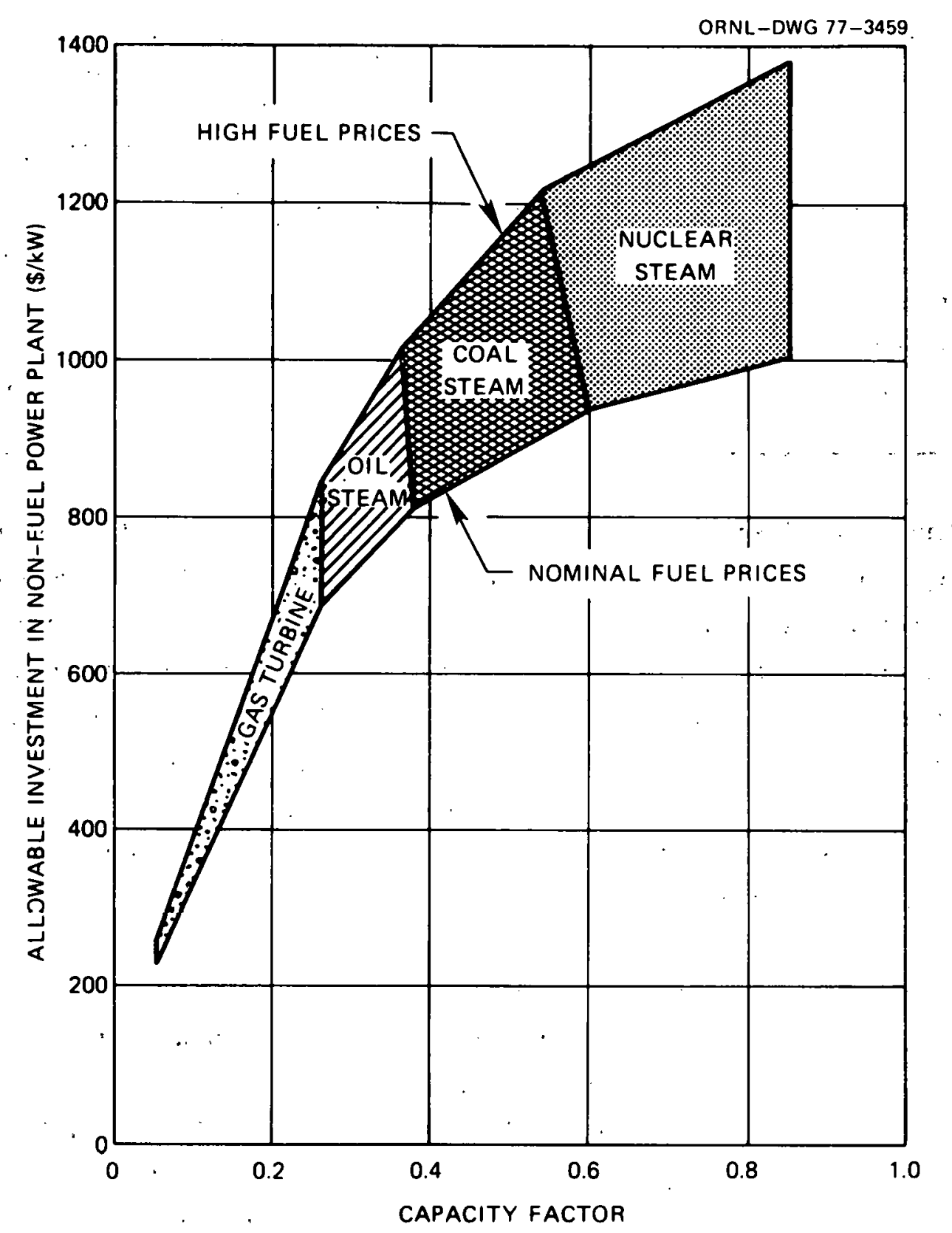

Fig. 6. Allowable investment in non-fuel power plant competing with conventional power plants, year 2000 . 
Table 9. Allowable investment for nonfuel power plants replacing conventional power plants (year 2000)

\begin{tabular}{lccc}
\hline $\begin{array}{c}\text { Conventional } \\
\text { plant }\end{array}$ & $\begin{array}{c}\text { Typical } \\
\text { capacity factor }\end{array}$ & \multicolumn{2}{c}{$\begin{array}{c}\text { Allowable investment } \\
\text { in non fuel plant } \\
(\$ / \mathrm{kW})\end{array}$} \\
\hline Gas turbine & 10 & $\begin{array}{c}\text { Nominal } \\
\text { fuel prices }\end{array}$ & $\begin{array}{c}\text { High } \\
\text { ruel prices }\end{array}$ \\
Oil, steam & 30 & 339 & 398 \\
Coal, steam & 50 & 738 & 916 \\
Nuelear, LWR & 70 & 885 & 1179 \\
& & 962 & 1302 \\
\hline
\end{tabular}

Margin requirements (backup capacity) and solar capacity factors were investigated for focusing ( $\mathrm{TC}$ and $\mathrm{PV}$ ) and nonfocusing (PV) solar power plants in two different hypothetical power systems. Example results given here are based on a 20,000-MWe base-load power system consisting initially of 20 conventional units. The conventional units were replaced one-by-one with solar base-load power plants, and the change in backup capacity required to maintain system reliability was estimated. The reliability criterion employed is the commonly-used utility requirement that the power system must fail to meet demand no more than one day in 10 years. Backup capacity was assumed to be supplied by gas turbines of $100 \mathrm{MWe}$ each. Figure 7 shows the amount of backup capacity required as a function of solar penetration for the last solar unit installed. The cumulative total backup capacity as a function of solar penetration is shown in Fig. 8.

Although the margin analysis is for a hypothetical system, the results are instructive. For very small solar capacity relative to system capacity, the solar plant is as effective as conventional plants in displacing capacity (see Fig. 7). But as the relative amount of solar capacity increases, the backup needed to maintain system reliability rapidly approaches $100 \%$. Intuitively, this would seem to be a serious penalty for solar replacement power plants but, in fact, it is much less than would be expected. First, if the backup is provided by gas turbines, the maximum capital investment penalty is $\$ 125 / \mathrm{kW}$. Secondly, the conventional power plants considered 


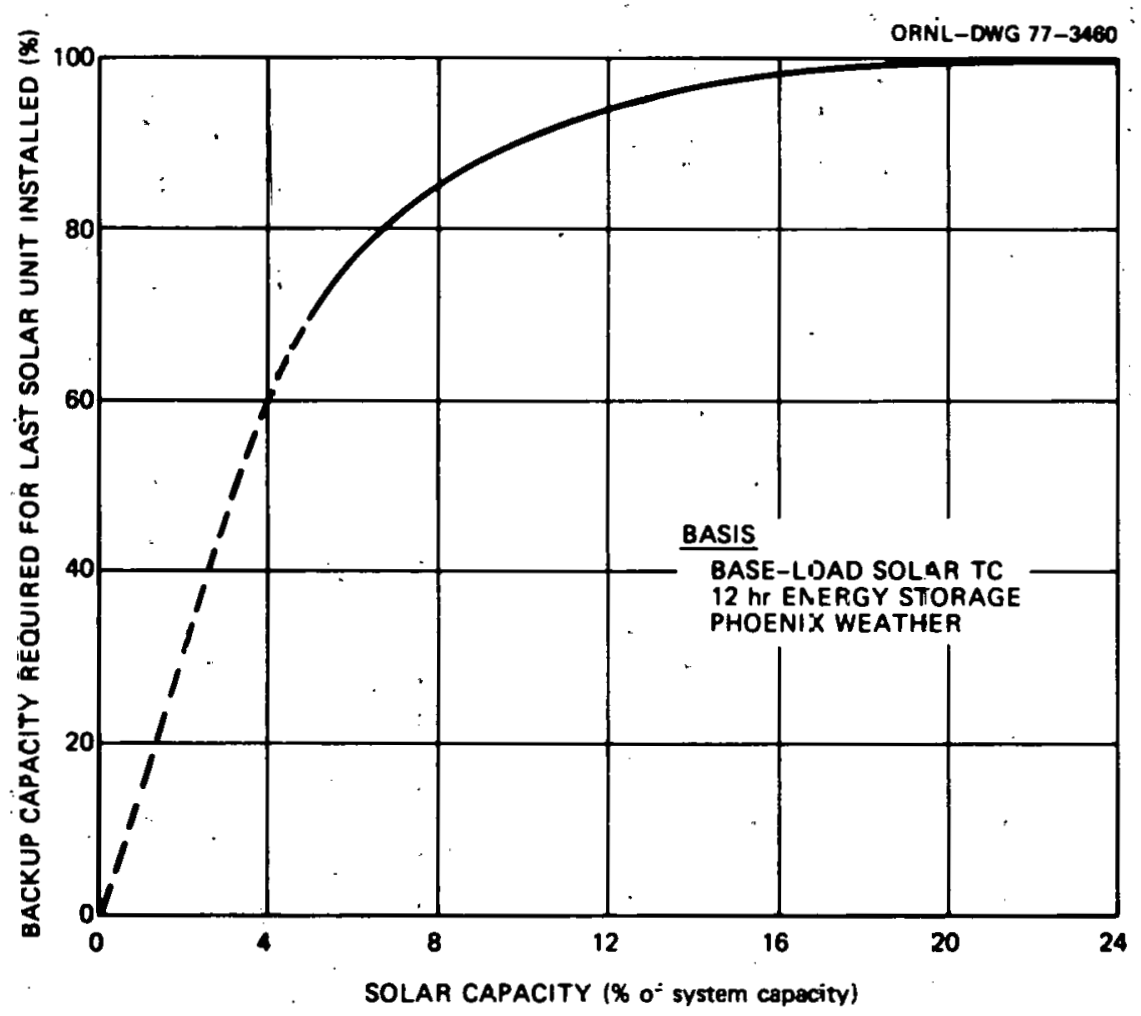

Fig. 7. :Backup capacity required to maintain system reliability, 20,000-MWe system consisting of 20 base-load power plants.

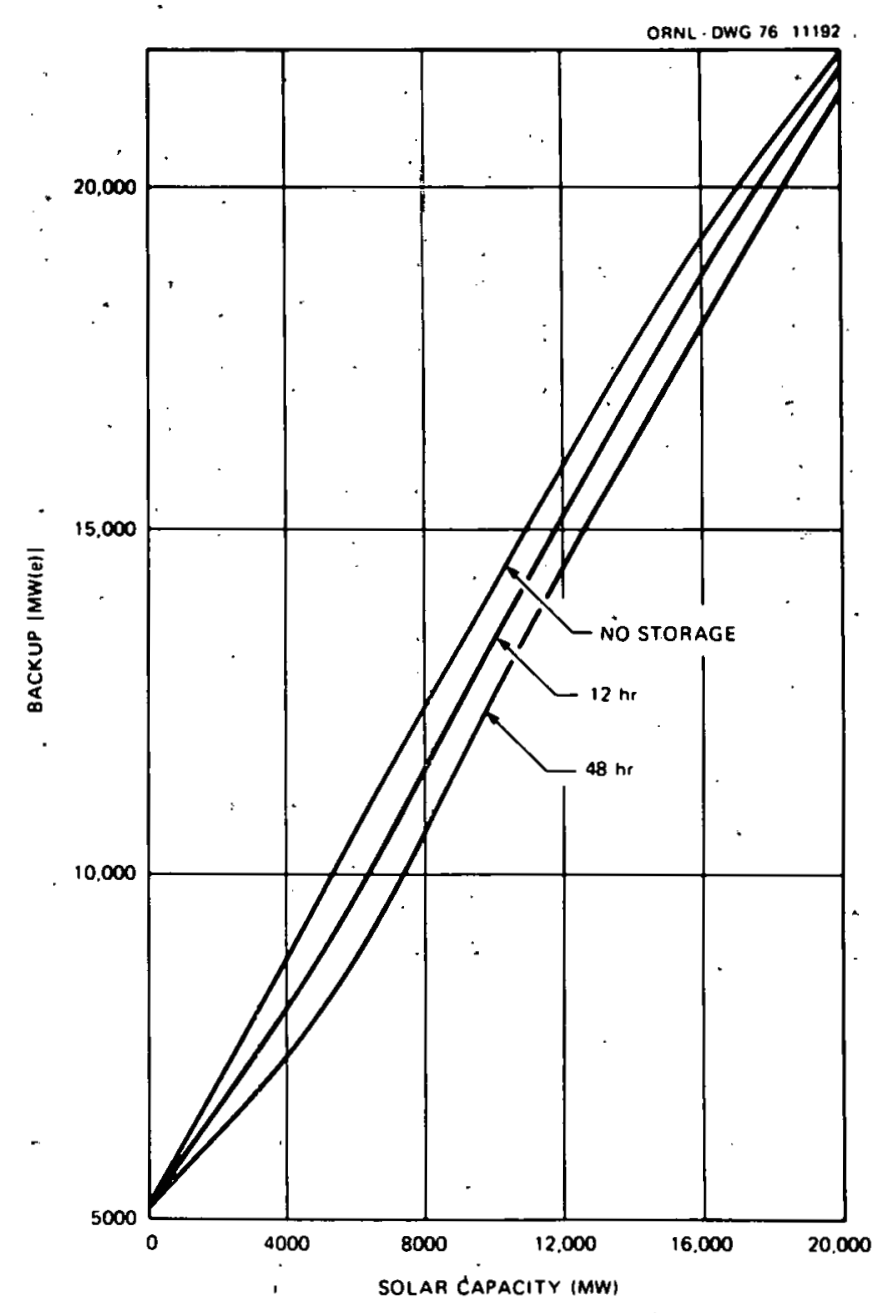

Fig. 8. Cumulative backup requirements as a function of solar generating capacity for a range of energy storage, 20,000-MWe power system. 
in the margin analysis would require $26 \%$ backup. Thus the penalty relative to conventional plants would be less than $\$ 100 / \mathrm{kW}$. Some perspective on this is given by the analysis below.

It was shown earlier that the allowable investment in a nonfuel power plant replacing a nuclear base-load power plant is about $\$ 1300 / \mathrm{kW}$ assuming the high year-2000 fuel prices. How this budget may be distributed among the cost elements of a solar base-load power plant is illustrated in Figs. 9 and 10. Figure 9 is for a thermal conversion or photovoltaic power plant operating on direct sunlight only (focusing lype). In this case the combination of collector size and storage capacity was not sufficient to bring the capacity factor up to the required value $(70 \%)$. Gas turbines made up the energy deficit and the capitalized value of the fuel burned is shown. Figure 10 is for a solar power plant operating on total sunlight (nonfocusing type). In this case the capacity factor was sufficient and no supplemental energy from gas turbines was required. Figures 9 and 10 indicate that the allowable investment in a solar base-load power plant is $\$ 700$ to $\$ 950 / \mathrm{kW}$ excluding storage and backup and assuming that fuel prices reach the high level assumed in this study for the year 2000 .

The above analysis suggests a simple and reasonably valid way of viewing a solar replacement power plant. The total power plant consists of solar components and gas turbines. The gas turbines provide the capacity (from the standpoint of system reliability) and the sular components provide the energy. The solar components, including energy storage, should be designed so that the capacity factor and timing of energy sendout are appropriate for the application (base-, intermediate-, or peak-load) proposed.

\section{Cost Targets for OI'EC Yower Plants}

Ocean Thermal Energy Conversion (OTEC) systems differ from the other solar power plants considered in this study in that they are capable of supplying firm power without energy storage. OTEC power plants are of greatest interest for base-load operation. Target costs for OTEC were developed for three potential applications: (1) supply of electricity to conventional electrolytic processes such as aluminum production, 


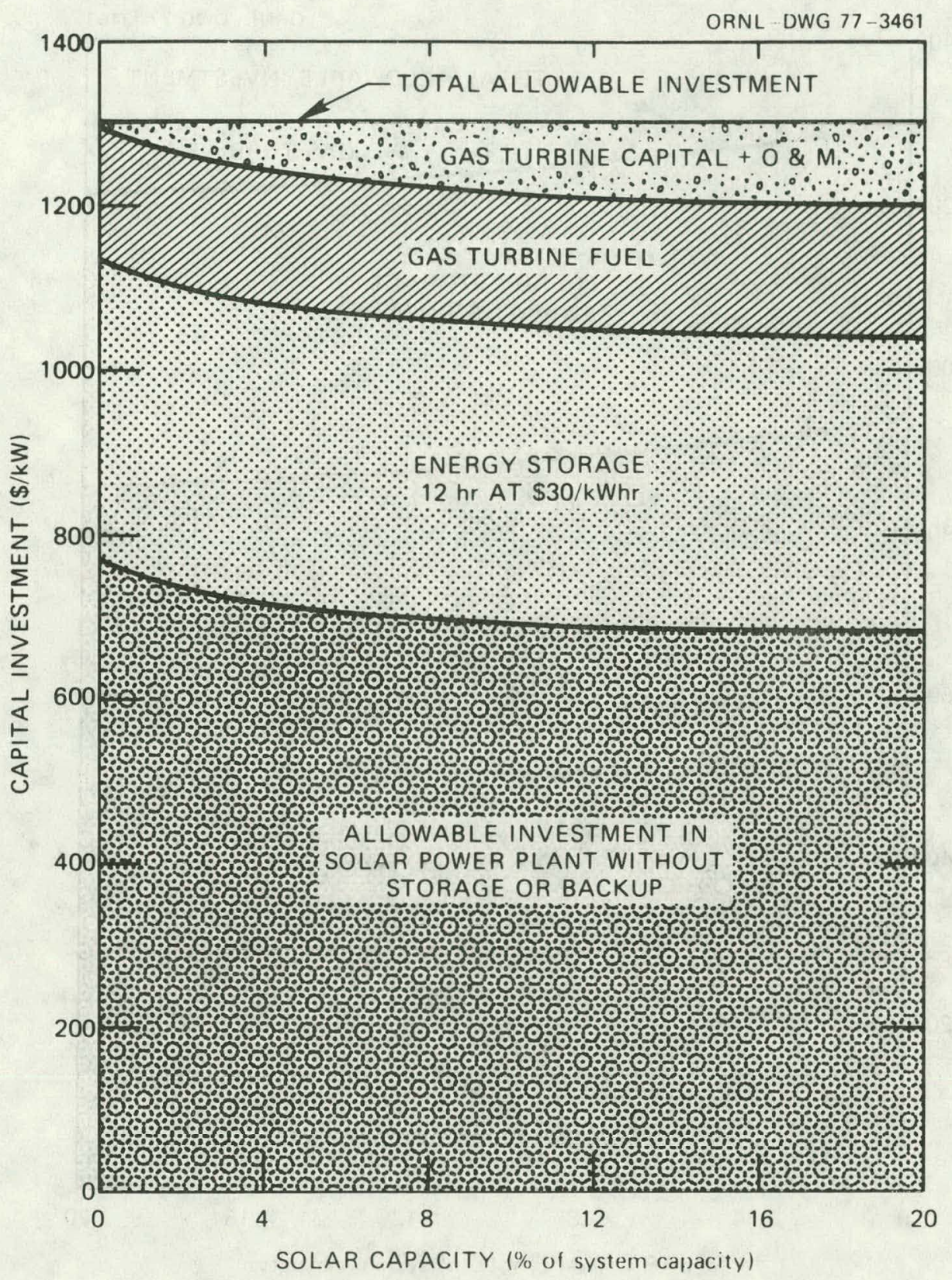

Fig. 9. Allowable investment in solar base load power plant operating on direct sunlight, Phoenix weather, year 2000 high fuel prices. 


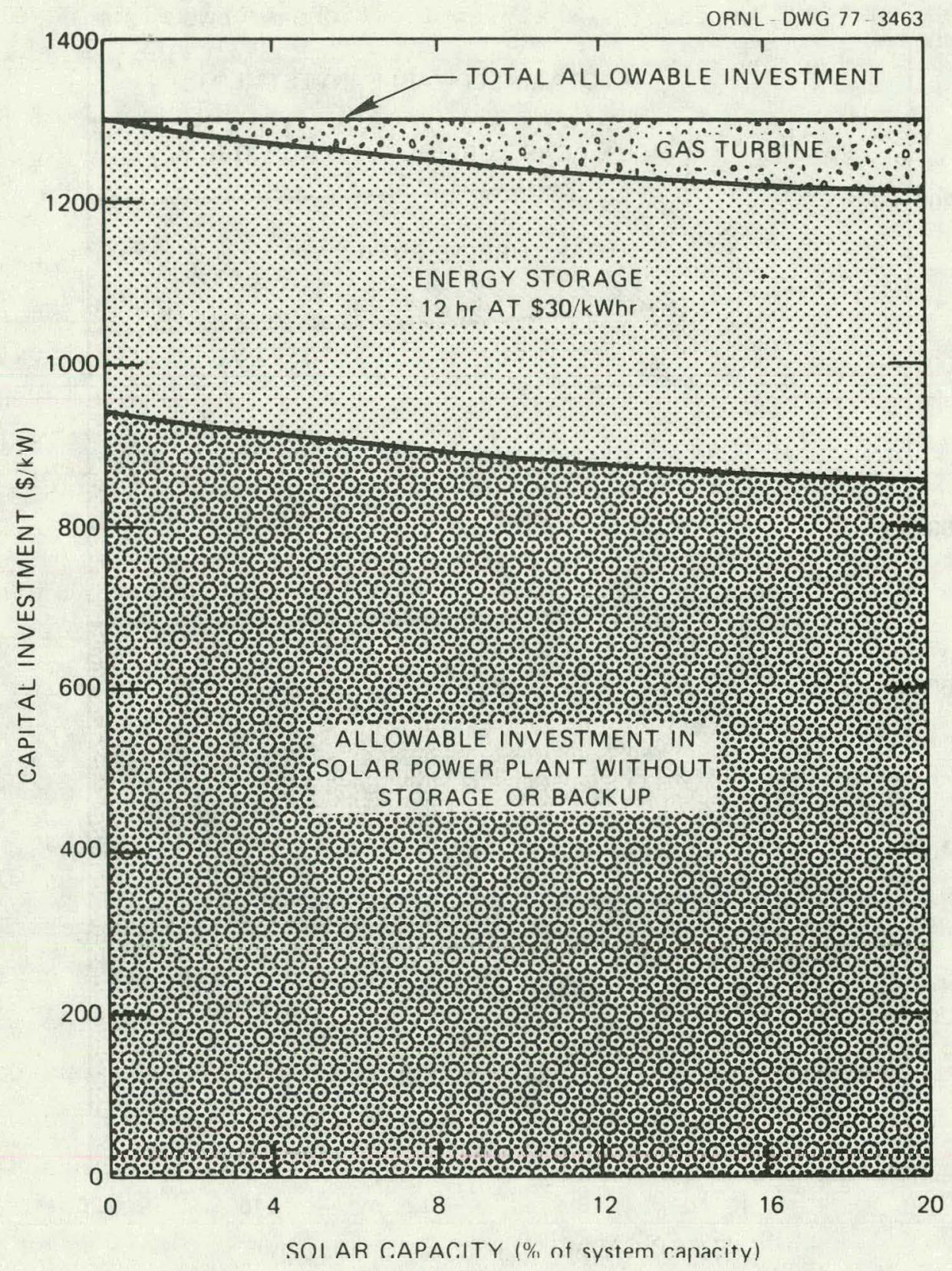

Fig. 10. Allowable investment in solar base load power plant operating on direct plus diffuse sunlight, Phoenix weather, year 2000 high fuel prices. 
(2) supply of base-load power to a utility grid, and (3) supply of electricity for electrolytic hydrogen production. The lowest cost conventional alternative to OTEC for each of these applications was used to develop target costs. In the first two applications (i.e., conventional electrolytic processes and base-load utility power), nuclear is the lowest cost conventional alternative. For the production of hydrogen, coal gasification was found to be the lowest cost conventional alternative.

In conventional electrolytic applications the value of an OTEC plant in relation to nuclear can be determined on the basis of busbar electricity generation cost if it is assumed that the cost of the electrolytic plant is the same whether it is located in the ocean or on land. Based on the previousily described results for the value of a nonfuel plant relative to nuclear, the amount that could be afforded for OTEC is $\$ 962$ and $\$ 1302 / \mathrm{kW}$ for the nominal and high year-2000 fuel prices, respectively.

The allowable cost for an OTEC supplying base-load power to a utility grid will depend on the unit capital cost and length of the submarine transmission line. Figure 11 shows the allowable cost for OTEC as a function of distance offshore with a transmission system unit cost of $\$ 3.11 / \mathrm{kW} . \mathrm{km}$ ( $\$ 5 /$ $\mathrm{kW} . \mathrm{mile})$. Similar results based on a transmission cost of $\$ 6.22 / \mathrm{kW} . \mathrm{km}$ (10/kW.mile) are given in Fig. 1?.

Concerning the production of hydrogen, one alternative to an OTECpowered electrolyzer would be hydrogen production through the gasification of coal. The allowable investment for OTEC when competing with coal as a source of hydrogen is shown in Fig. 13 as a function of the price of coal.

Comparative cost targets for OTEC for the three applications considered are summarized in Table 10. The ranking in decreasing order of economic feasibility is: (1) conventional electrolytic processes, (2) base load power for utility grid, and (3) electrolytic hydrogen production. 


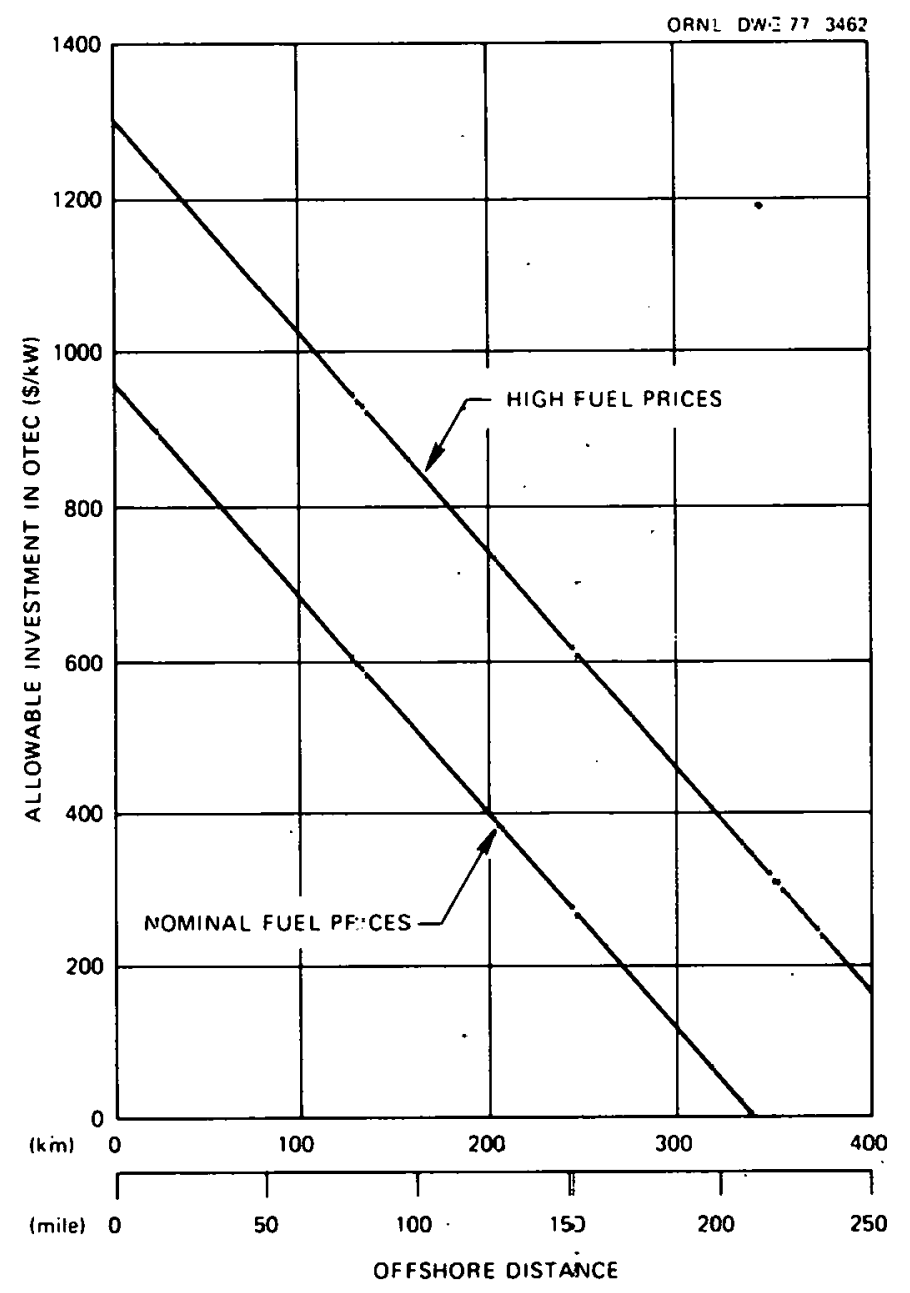

Fig. 11. Cost targets for OTEC supplying base load power, transmission systen cost of $\$ 5 / \mathrm{kW}$. mile $(\$ 3.11 / \mathrm{kW} . \mathrm{km})$.

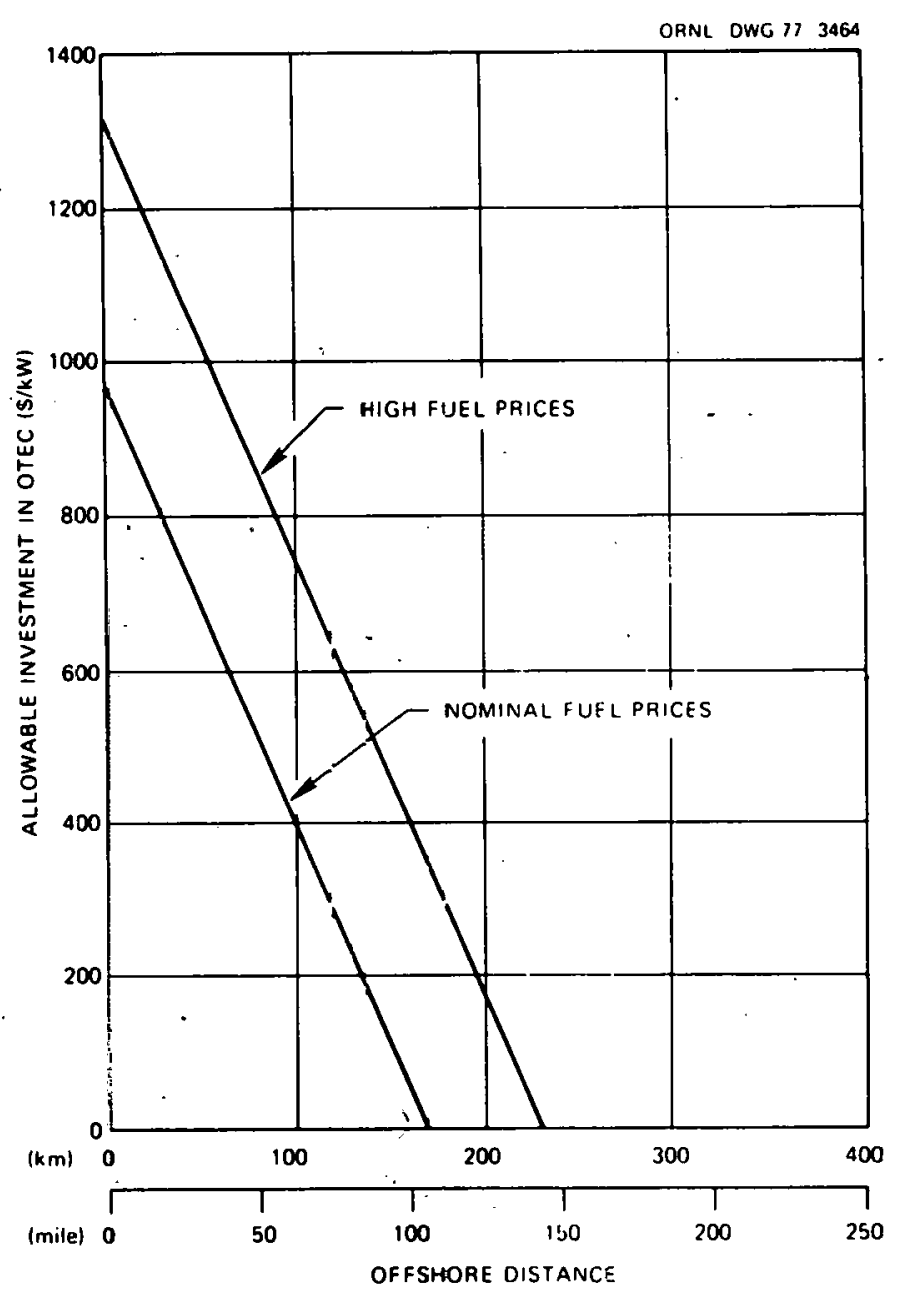

Fig. 12. Cast targets for OTEC supplying base load power, transmission system cost of $\$ 10 / \mathrm{kW} . \mathrm{mile}(\$ 6.22 / \mathrm{kW} . \mathrm{km})$. 


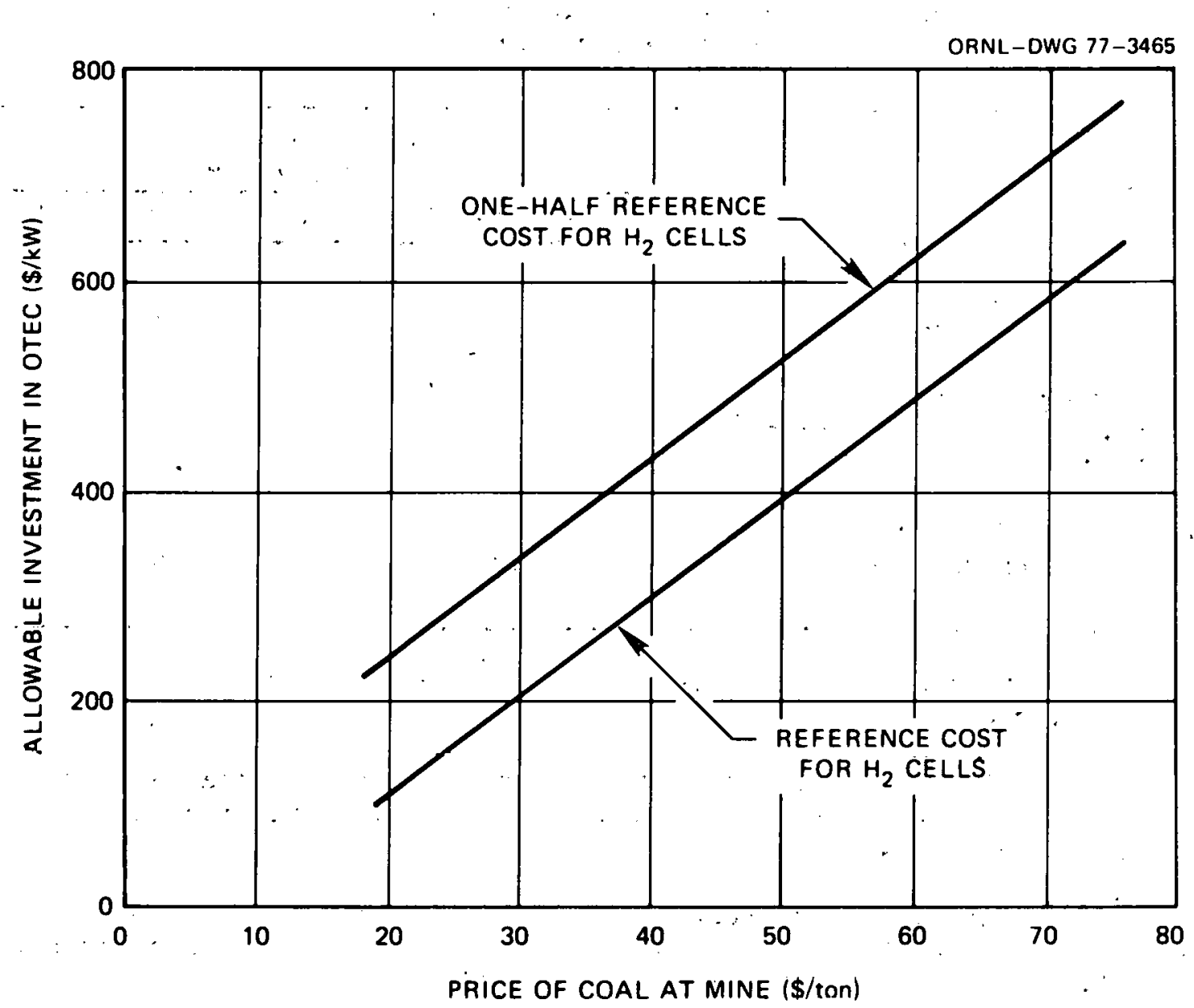

Fig. 13. Cost targets for OTEC producing electrolytic hydrogen in competition with hydrogen production from coal. 
Table 10. Cost targets for OTEC, year 2000

(mid-1976 dollars)

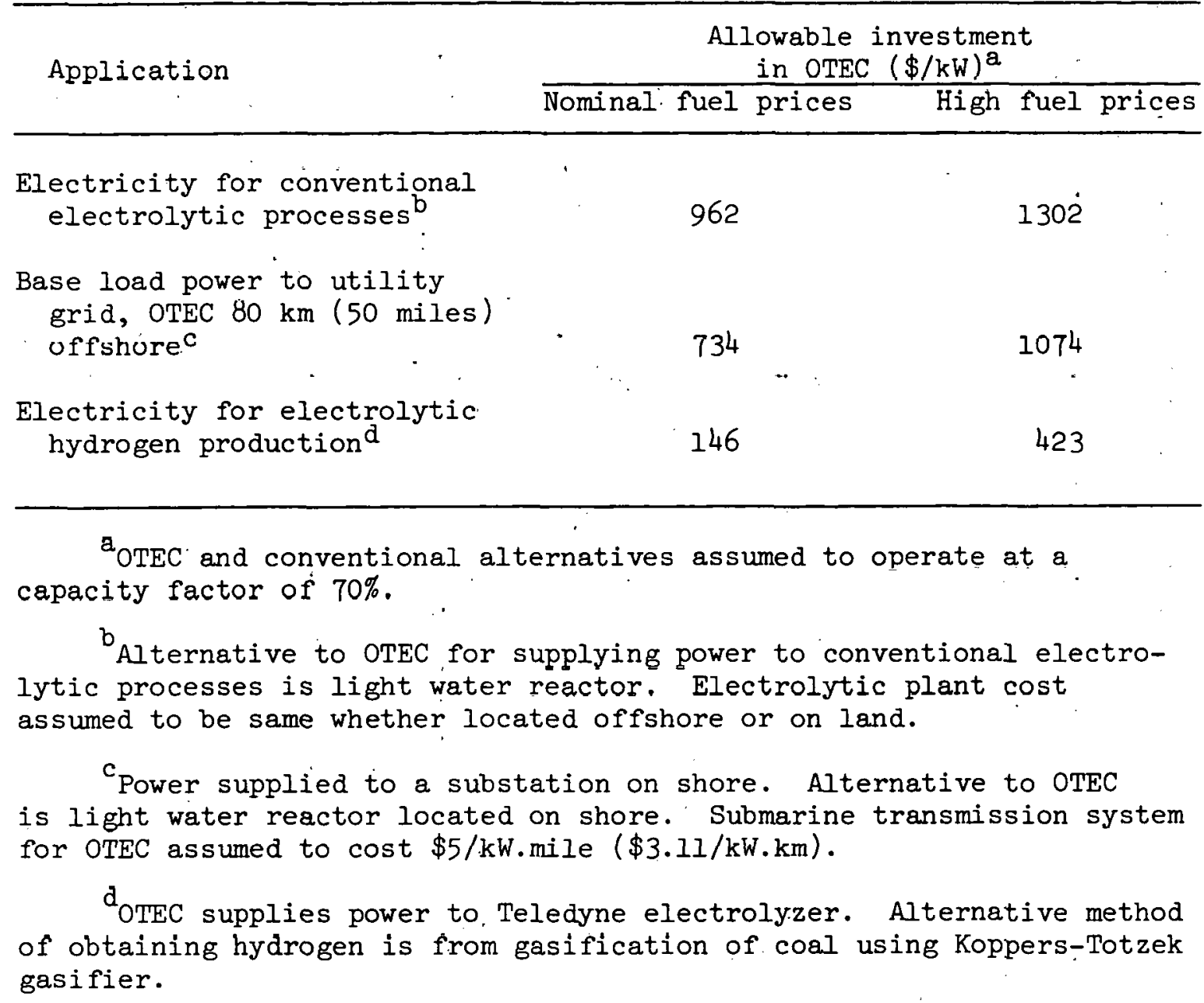


CONCLUSIONS AND RECOMMENDATIONS

Based on the results of this study, it would appear that the derivation of comparative cost targets is one means by which ERDA can rank solar electric technologies and proposed applications. To determine cost targets, it is necessary to characterize the expected future power system, with respect to both composition and cost, into which solar is to be introduced. The present investigation was based on an assumed national energy-mix for the year 2000, but it is recognized that regional patterns of energy generation and demand could be of significance relative to solar-electric applications. It is recommended that regional variations be considered in future studies of this nature. Since perceptions of future energy options and their costs are constantly changing, it is further recommended that periodic reevaluations of solar cost targets be made to provide an upto-date basis for solar R\&D planning.

One straightforward and potentially useful application of wind, solar thermal, and solar photovoltaic is as supplemental (energydisplacing) power plants. The value (or what can be afforded) for such power plants declines as market penetration increases. To determine the value of supplemental power plants as a function of generating capability, it is necessary to analyze specific power systems using a load dispatching model. It is recommended that ERDA develop a dispatching model, which treats solar and wind power plants in an explicit manner, as a tool for examining supplemental power applications.

- One of the better applications of solar thermal conversion power plants is as a supplemental energy source in a hybrid (solar-fossil) configuration. It is recommended that ERDA undertake design, cost, and performance studes of the hyorld cuncepl.

The greatest market potential for wind, thermal conversion, and photovoltaic power plants would be as direct-replacements for conventional power plants. This application will require the development of low-cost energy storage. Presumably this energy storage 
technology could also be applied to conventional power plants to improve their economic performance; this factor was not considered in the present study. Thus, a major unanswered question is whether the development of low-cost energy storage technology would improve the position of solar power relative to conventional power. The answer could be important in structuring solar R\&D programs. It is recommended that comparative studies be made to determine the effect on solar-electric cost targets of applying energy storage to conventional power plants as well as solar power plants.

The ranking in decreasing order of economic feasibility of OTEC applications appears to be (1) conventional electric processes such as aluminum production, (2) base-load power to utility grid, and (3) hydrogen production by electrolysis. The production of hydrogen by electrolysis, whether the electric power source be OTEC or any other power plant considered in this study, appears to be economically unattractive relative to the production of hydrogen through coal gasification. . 
REFERENCES

1. A National Plan for Energy Research, Development and Demonstration: Creating Energy Choices for the Future, 1976, ERDA 76-1, Vol. 1, U.S. Energy Research and Development Administration, Washington, D.C., April 1976.

2. Truman D. Anderson, H. I. Bowers, et al., An Exploratory Study of Cost Targets for Solar Electric Power Plants, ORNL/TM-5788 (in publication).

3. Testimony of Roger W. A. Legassie, Hearings on Growth Rates of Electricity and the Role of Nuclear Energy, United States Committee on Interior and Insular Affairs, Subcommittee on Energy and the Environment, April 28, 1975.

4. National Energy Outlook, Federal Energy Administration, FEA-N-75/T13, February 1976.

5. Walter G. Dupree, Jr., and John S. Corsentino, United States Energy Through the Year 2000 (Revised), Bureau of Mines, U.S. Department of Interior, December 1975.

6. Energy Perspectives 2, U.S. Department of the Interior, June 1976.

7. Chauncey Starr, "The Year 2000: Energy Enough?" EPRI Journal, No. 5, June 1976. 
THIS PAGE

WAS INTENTIONALLY

LEFT BLANK 
ORNL/TM-5787

\section{INTERNAL DISTRIBUTION}

$\begin{array}{cl}\text { 1-26. } & \text { T. D. Anderson } \\ 27 . & \text { Seymour Baron } \\ \text { 28. } & \text { S. E. Beall } \\ \text { 29. } & \text { H. I. Bowers } \\ \text { 30. } & \text { R. S. Carlsmith } \\ \text { 31. } & \text { Wm. E. Cooper } \\ \text { 32. } & \text { F. L. Culler } \\ \text { 33. } & \text { J. G. Delene } \\ \text { 34. } & \text { G. G. Fee } \\ \text { 35. } & \text { W. Fulkerson } \\ \text { 36. } & \text { L. C. Fuller } \\ \text { 37. } & \text { M. J. Goglia } \\ \text { 38. } & \text { J. F. Harvey } \\ \text { 39. } & \text { S. I. Kaplan }\end{array}$
40. Milton Levenson

41. R. S. Livingston

42. J. W. Michel

43. H. Postma

44. M. W. Rosenthal

45. I. Spiewak

46. D. B. Trauger

47. Wm. J. Wilcox

48. J. V. Wilson

49. ORNL Patent Office

50-51. Central Research Library

52. Document Reference Section

53-55. Laboratory Records Department

56. Laboratory Records (RC)

\section{EXTERNAL DISTRIBUTION}

57-62. Director, Division of Solar Energy, ERDA, Washington, D.C. 20545

63. Howard S. Coleman, Deputy Director, Division of Solar Energy, ERDA, Washington, D.C. 20545

64-73. J. E. Rannels, Chief, Total Energy Systems Branch, Division of Solar Energy, ERDA, Washington, D.C. 20545

74. Richard H. Blieden, Assistant Director for Biomass, Ocean, and Wind Systems, Division of Solar Energy, ERDA, Washington, D.C. 20545

75. Louis V. Divone, Chief, Wind Systems Branch, Division of Solar Energy, ERDA, Washington, D.C. 20545

76. S. Gronich, Chief, Ocean Systems Branch, Division of Solar Energy, ERDA, Washington, D.C. 20545

77. Fred Koomanoff, Chief, Environmental and Resource Studies Branch, Division of Solar Energy, ERDA, Washington, D.C. 20545

78. Morton L. Prince, Assistant Director for Photovoltaics, Division of Solar Energy, ERDA, Washington, D.C. 20545

79. George Kaplan, Chief, Central Receiver Systems Branch, Division of Solar Energy, ERDA, Washington, D.C. 20545

80. Paul Maycock, Coordinator for Planning and Implementation, Division of Solar Energy, ERDA, Washington, D.C. 20545

81. C. R. Mandelbaum, Planning, Analysis and Evaluation, ERDA, 20 Mass. Ave., N.W., Washington, D.C. 20545. Mail Stop 7127

82. Lloyd C. Trimble, Lockheed Missiles and Space Company, P.O. Box 504, Sunnyvale, Calif. 94088

83. Robert H. Douglass, Jr., TRW Systems, I Space Park, Redondo Beach, Calif. 90278

84. William E. Heronemus, Dept. of Civil Engineering, Marston Hall, University of Massachusetts, Amherst, Mass. 01002 
85. Clarence Zener, Carnegie-Mellon University, Schenley Park, Pittsburgh, Pennsylvania 15213

86. William H. Avery, The Johns Hopkins University, Applied Physics Laboratory, 11100 Johns Hopkins Road, Laurel, Md. 20810

87. Marty Scholl, MITRE Corporation, Westgate Research Park, McLean, Virginia 22101

88. Piet Bos, EPRI, P.0. Box 10412, Palo Alto, Calif. 94303

89. George C. McKoy, The Aerospace Corp., Energy and Transportation Division, 2250 E. El Segundo Blvd., El Segundo, Calif. 90045

90. Gerald Braun, Southern California Edison Co., P.0. Box 800, Rosemead, Calif. 91770

91. James Leonard, Sandia Laboratories, Advanced Energy Products Division, Alvuyuerque, New Mexicu 87115

92. Donald G. Schueler, Manager, ERDA Photovoltaic Systems Definition Program, Sandia Laboratories, Box 5800, Albuquerque, New Mexico 87115

93. Harold L. Falkenberry, Chief, Power Research Staff, Tennessee Valley Authority, Evans Building, Chattanooga, Tenn. 37401

94. Richard S. Caputo, Thermal Energy Conversion Group, Jet Propulsion Laboratory, 4800 Oak Grove Drive, Pasadena, Calif. 91103

95. Richard H. Braasch, Sandia Laboratories, Advanced Energy Froducts Division, Albuquerque, New Mexico 87115

96. A. M. Perry, Institute for Energy Analysis, Oak Ridge Associated Universities, P.0. Box 117, Oak Ridge, Tenn. 37830

97. W. G. Pollard, Institute for Energy Analysis, Oak Ridge Associated Universities, P.0. Box 117, Oak Ridge, Tenn. 37830

98. John Day, Advanced Systems Technology Division, Westinghouse Corporation, Advanced Systems Technology Division, 700 Braddock Avenue, East Pittsburgh, Pa. 15112

99. J. A. Lenhard, Research and Technical Support Division, ERDA, ORO, Oak Ridge, Tenn. 37830

100. J. R. Blevins, Research and Technical Support Division, ERDA, ORO, Oak Ridge, Tenn. 37830

101-127. Technical Information Center, ERDA, ORO, Oak Ridge, Tenn. 37830 